Island Studies Journal, Vol. 12, No. 1, 2017, 223-242

\title{
The competitive value of territorial resources for photovoltaic energy on the island of Gran Canaria
}

Francisco Santana Sarmiento

Universidad de Las Palmas de Gran Canaria, Spain

franciscojesus.santana@ulpgc.es

Francisca Rosa Álamo Vera

Universidad de Las Palmas de Gran Canaria, Spain

francisca.alamo@ulpgc.es

and

Petra De Saá Pérez

Universidad de Las Palmas de Gran Canaria, Spain

petra.desaaperez@ulpgc.es

ABSTRACT: This work aims to identify the most suitable location for photovoltaic power plants on the Spanish island of Gran Canaria. To that end, we propose a methodology which will assess those physical territorial resources involved in the development of photovoltaic solar energy by means of two devices: the available territorial resource map and the available territorial resource index. In order to achieve this objective, multi-criteria analysis through an analytical hierarchy process with geographical information systems was used. The empirical analysis concluded that a large percentage of the island territory enjoys excellent potential for the setting-up of photovoltaic plants. The contribution of this research is particularly important in an island context, since it is in this type of territory where such tools are especially relevant to plan the best use of limited land area and availability.

Keywords: Canary Islands, GIS, Gran Canaria, islands, land use, multi-criteria assessment, photovoltaic energy, territorial resource

https://doi.org/10.24043/isj.14

(c) 2017 - Institute of Island Studies, University of Prince Edward Island, Canada.

\section{Introduction}

In this article, we will focus on the analysis of the territorial resources for the potential development of photovoltaic energy in Gran Canaria, one of the two main islands of the Canarian archipelago, Spain, formed by seven islands (see Figure 1). Gran Canaria is located in the centre of the archipelago, with a land surface area of $1,560 \mathrm{~km}^{2}$ spread over 21 municipalities, and with 847,830 inhabitants in 2015 (Canarian Statistics Institute, 2016). This archipelago is located in the North East of Africa, between the latitudes 27 $7^{\circ} 37^{\prime}$ and $29^{\circ} 5^{\prime} \mathrm{N}$ and the longitudes $13^{\circ} 20^{\prime}$ and $18^{\circ} 10^{\prime} \mathrm{W}$. Its geographic fragmentation, its distance from the large 
energy production plants (located $1,000 \mathrm{~km}$ away from mainland Spain), and the lack of conventional energy resources have created a critical dependence on oil-based imports (Bueno \& Carta, 2006).

Figure 1: Geographical location of the Canarian archipelago.

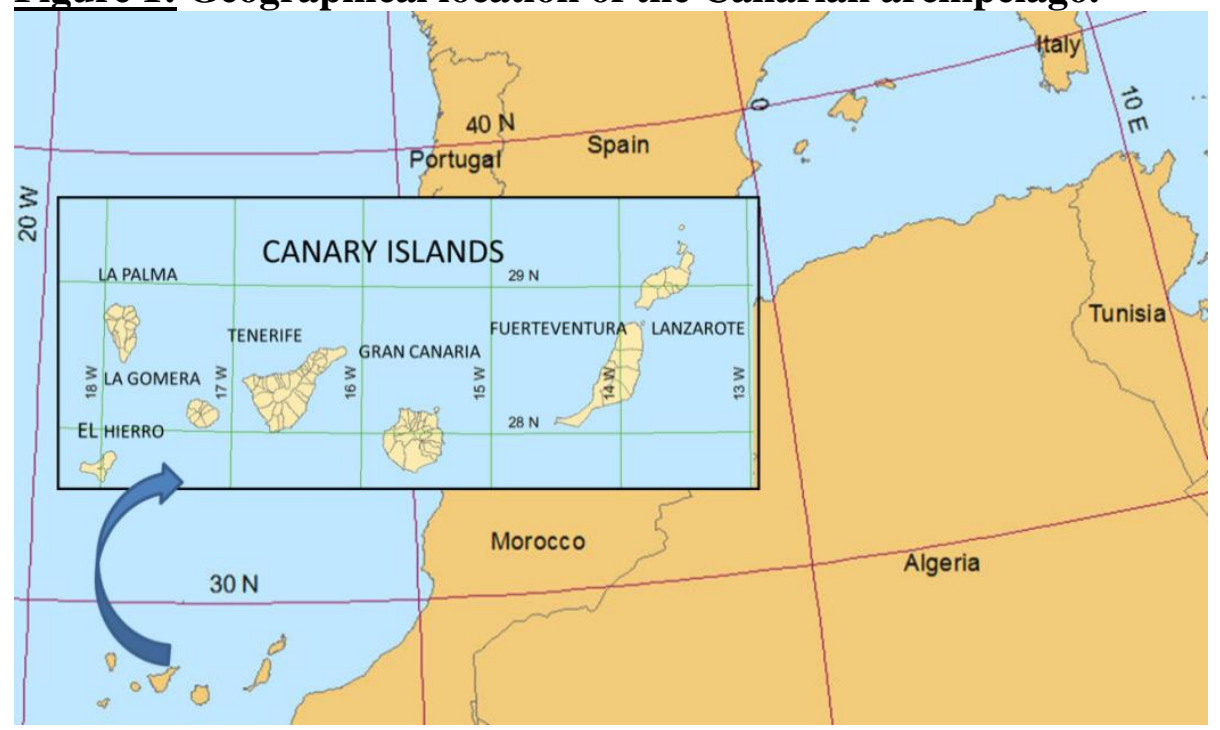

Source: Prepared from the Natural Earth project (http://www.naturalearthdata.com) and GRAFCAN.

Energy is considered a key factor in sustainable development, to such an extent that the future of the planet may well depend on how this energy can be obtained and used (Calero, 2011). This is the case for islands where there is an increasing demand for energy. In addition, the environmental and social concerns related to fossil fuels create the conditions for researching alternative and more viable energy sources. The current energy model is questionable, especially when renewable energy is being favoured for its unlimited features, its more homogenous territorial distribution, and its ability to avoid producing dangerous waste. In this regard, the Europe 2020 strategy (2010) proposes that renewable energy should reach $20 \%$ of energy consumption of the EU by 2020, as well as a $20 \%$ reduction in $\mathrm{CO}_{2}$ emissions, with the aim of creating a model of sustainable economic development that safeguards energy supply, competitiveness, and environmental sustainability. In this vein, Del Río and Burguillo (2009, p. 1315) state that:

renewable energy sources (RES) have a large potential to contribute to the sustainable development of specific territories by providing them with a wide variety of socioeconomic benefits, including diversification of energy supply, enhanced regional and rural development opportunities, creation of a domestic industry and employment opportunities.

One of these alternatives, solar energy, is easily available in tropical locations, such as the Canary Islands.

Islands and islanders could benefit from economic, social, and environmental gains by switching to solar energy. From an economic perspective, large electricity systems are not efficient in small islands, because economies of scale are not feasible, even with the lower cost of petroleum these days; therefore, an alternative energy model-different from those used in 
continental regions-is necessary (Perez \& Ramos Real, 2008). Social benefits are also involved, as the quality of life of the original population could be increased, since the higher costs involved in procuring fossil sources of energy are averted; while solar energy is an 'infinite' and freely available resource. And from an environmental point of view, the use of green energies helps combat climate change, by reducing acid rain and global warming. As islands are threatened by the rising of ocean water levels caused by global warming, renewable energy sources - and especially solar energy — would be friendlier resources if they were to be used in these territories.

According to data from the Energy Report by the Canary Islands Government (2016), in 2014 the energy demand of electric power in the Canaries showed an $88.2 \%$ dependence on oil. The rest of the energy consumption has been covered mainly by the generation of electricity through renewable energy (11.8\%), with 5.9\% of photovoltaic power. However, this data does not reflect the significant potential that this archipelago has to generate photovoltaic energy (Monedero et al., 2013) in relation to available resources.

The Canary Islands Government (2016) reports that, in 2014, renewable energy generation in Gran Canaria represented $10.9 \%$ of total energy, $0.9 \%$ below the archipelago average and far from the $20 \%$ goal of Europe 2020. With regards to photovoltaic energy, 39.3MW were installed in Gran Canaria, which is only $3.4 \%$ of total energy and $2.5 \%$ below the archipelago average. This data reveals the need for a more effective use of this kind of energy in order to adjust available resources to existing demand in a more sustainable way. In this way, the use of autonomous energy sources is essential to achieve the most important energy objectives on the island: the reduction of supply vulnerability, the decrease in external energy dependence, to minimize the cost of energy, and the protection and preservation of the environment (Calero \& Carta, 2004).

The reasons for focusing the empirical study on the photovoltaic sub-sector of renewable energy industry are three-fold: (a) this sector is likely to offer interesting business opportunities; (b) it is a strategic sector for the economic growth in Spain, as well as in the Canary Islands; and (c) it is an economic activity where location is a key success factor, as firms usually intend to optimize natural resources. Finally, the implementation of photovoltaic power in the territory will be analyzed through 'solar farms', as the location of photovoltaic power stations in urban areas would require another type of analysis which integrates data of another nature such as the use of the building (residential, service, industrial), the quantity and forms of the surface areas of the buildings, and their viability to take on solar panels in relation to such issues as morphology, orientation and shadowing between buildings (Izquierdo et al., 2008; Schallenberg-Rodríguez, 2013; Wiginton et al., 2010).

According to the Europe 2020 strategy (2010), EU Member States should search for new economic growth opportunities in their environmental challenges, making a more efficient use of natural resources. As Balkytè and Peleckis (2010, p. 631) point out, "Being competitive or being only sustainable is easier than being sustainable and competitive at the same time," and a compatibility of both concepts should be generally recognized. In this line, Rutkauskas (2008) indicates that the competitiveness of a nation depends on its capacity to efficiently use available resources, as well as its ability to introduce innovation and positive changes in an environment that can assure sustainability. As Gallardo-Cobos et al. (2011) state, the territory is, in itself, a key strategic asset to achieve competitiveness, and it is necessary to create capacities to exploit it. In addition, Colletis-Wahl and Pecqueur (2001) consider that it is important to take into account not only active but also latent resources, as the latter could reveal new niches of endogenous 
productive activity in the territory that strengthens its innovation process. This aspect is even more important to islands given the specific socio-economic aspects of these territories: they tend to be smaller, far from mainlands, and form part of a wider fragmented region (Baldacchino, 2004). At EU level, regions with specific geographical characteristics, including islands, have received much "EU regional policy attention and their economic development is considered important in helping the EU to attain its important 'territorial cohesion' objective" (Armstrong et al., 2012, p. 177). Therefore, we need an estimate of the available natural resources in the territory to safeguard the sustainable competitiveness in the long term.

And yet, the geographical distribution of the territory's physical resources is not taken into account in most territorial competitiveness research (Deas \& Giordano, 2001; Dögl \& Holtbrügge, 2010; Huggins, 2003; Moon et al., 1998). The measurement is done in general terms

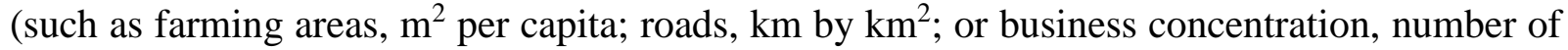
companies per capita), without specifying the exact location and the inter-relations among such resources. This should be taken into account when dealing with sectors such as energy, agriculture, or tourism, whose success and sustainability are based on the location of specific resources in a geographical area (Chhetri \& Arrowsmith, 2008; Eslami \& Roshani, 2009; Hajehforooshnia et al., 2011; Hossain et al., 2007; Pasqualini et al., 2011; Tiba et al., 2010).

Given this context, this work focuses on the available territorial resources for the development of photovoltaic energy on the island of Gran Canaria, where the use of the scarce land has to be 'optimized'. It proposes to simultaneously evaluate the combination of the physical territorial resources involved in the development of the photovoltaic energy through an available territorial resource map (ATRM) and an available territorial resource index (ATRI). The development of this energy in a territory requires a minimum amount of solar radiation in combination with other resources such as the power grids that transport generated energy, communication channels that favour the construction and maintenance of the installations, the orography, the available land, etc. Thus, the ATRM map aims to quantify the available resource and to interconnect all those factors that make the territory attractive. The ATRI index synthesizes the information of the map through a numerical value which enables to compare territories. On the basis of the information that both tools (ATRM and ATRI) offer, it is possible to set up a land use policy that prioritizes the best areas to settle a specific activity based on the use of natural resources. Therefore, in an insular context where disadvantage is notably significant in relation to the energy supply as it depends on the import of oil products, the use of tools such as the ones here proposed (ATRM and ATRI) is especially relevant to design an adequate land policy.

To accomplish our research goals, this paper is organized into four sections. After this introduction, the second section includes the empirical application of the methodological proposal to obtain the ATRM and ATRI. A third section is devoted to discuss the results. We conclude by reviewing the main outcomes of this work.

\section{Methodology}

The research work by Arán et al. (2008) was used as the supporting methodological framework to obtain the ATRM and ATRI. We describe an environmental decision-support system (EDSS) for selecting optimal sites for grid-connected photovoltaic power plants, combining multi-criteria analysis and the analytic hierarchy process with GIS and taking into account orography, location, and climate factors. The five stages needed to complete the process are set out in Figure 2. 
Figure 2: Methodology for available territorial resource map and index.

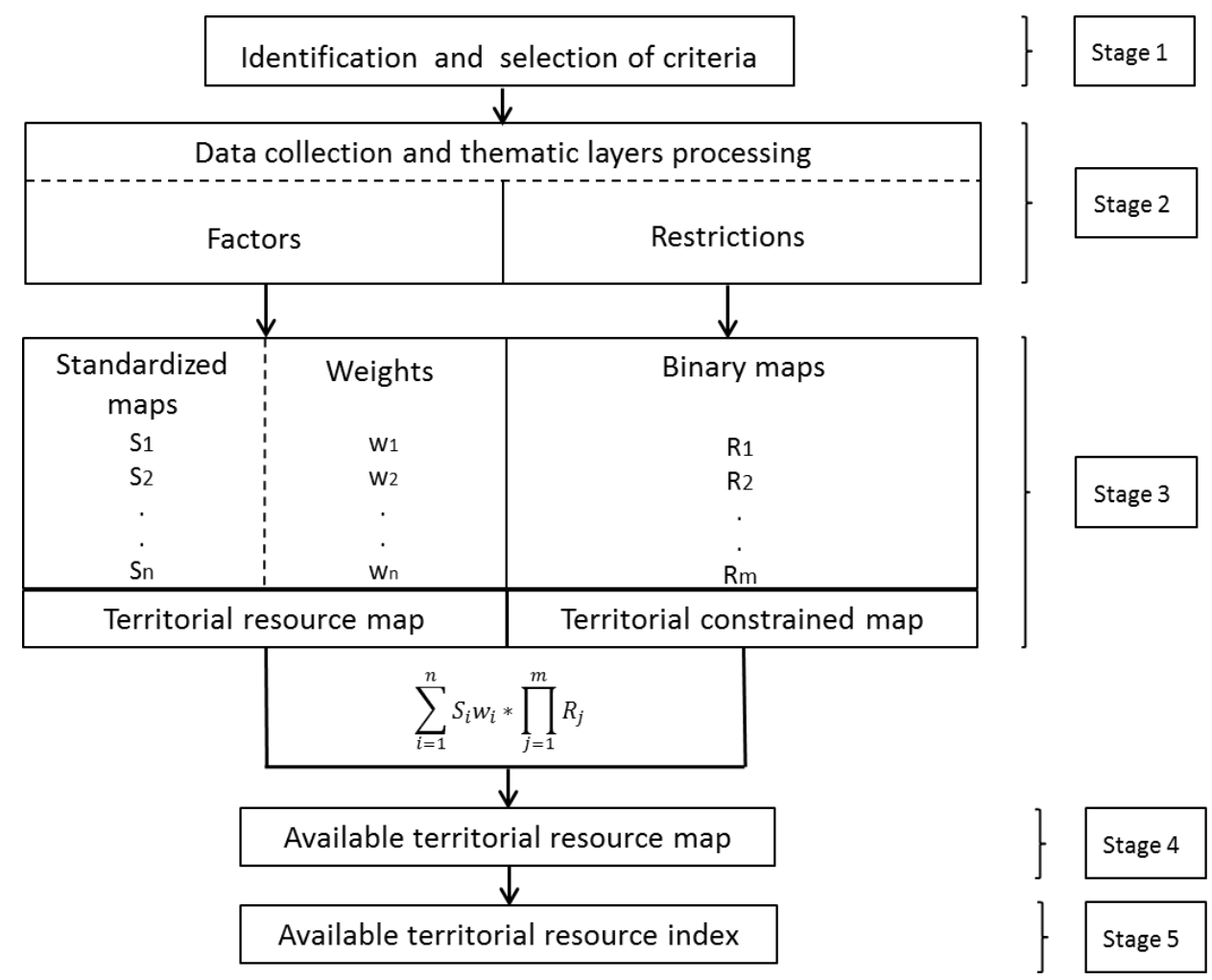

Source: Adapted from Tegou, Polatidis, \& Haralambopoulos (2010).

Stage 1: Identification and selection of criteria. The objective of the first stage is to select the criteria that are decisive for the evaluation of the territorial resources involved in the productive activity under study. As the resources related to the development of a specific productive activity are multiple, a multi-criteria analysis with geographic information systems (GIS) (Gómez \& Barredo, 2005; Malczewski, 1999, 2006) is used to obtain the ATRM. Geo-information enables the exact location of territorial resources from thematic layers, each one representing a resource (see Figure 3). The multi-criteria analysis used is based on an analytical hierarchy process developed by Saaty (1977), which consists of a linear weighted summation where the weights are calculated by establishing levels of hierarchy among the criteria. The relative importance among each criterion pair is established through pairwise comparison at each level. This method can be implemented in the GIS IDRISI software (Eastman, 2003) or as a macro for ArcGis (Marinoni, 2004). In recent years, the analytical hierarchy process has been commonly used because it is intuitive and easy to implement in GIS, leading to a significant advance in the quantity and quality of the research related to various techniques, including planning of urban infrastructures (Hajehforooshnia et al., 2011; Suárez-Vega et al., 2011; Yang et al., 2008), landscape modelling (Vizzari, 2011), location of facilities (Dey \& Ramcharan, 2008; Kontos et al., 2005; Tuzkaya et al, 2008; Wang et al., 2009), and the planning of renewable energy (Izquierdo et al., 2008; Omitaomu et al., 2012; Perpiña et al., 2013; Tegou et al., 2010). 


\section{Figure 3: GIS information obtained from the Canary Islands Government.}

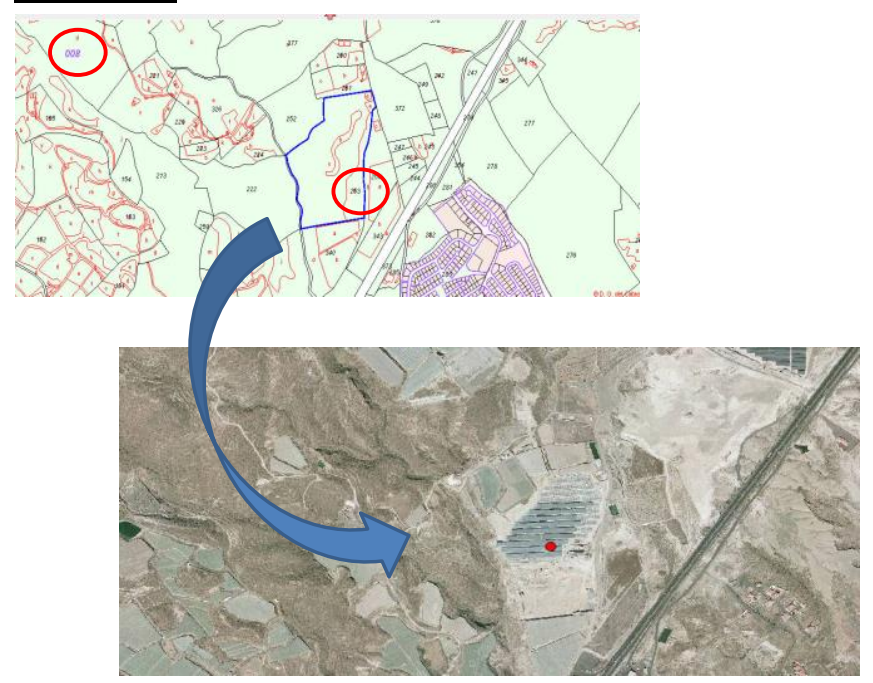

Source: Prepared from Catastro and GRAFCAN data.

Stage 2: Data collection and thematic layers processing. In the second stage, the criteria are added to the GIS via different thematic layers from the geo-information available in the Spatial Data Infrastructure (SDI) of the Canary Islands (https://www.idecanarias.es). Literature suggests that these criteria should be classified into facilitators and restrictions. In this work, nine factors were considered, based on different sources (e.g., Arán et al., 2008; Aydin et al., 2013) with the objective of finding the ideal location of photovoltaic power plants through GIS on Gran Canaria. They were grouped in two levels (Table 1): first-level and second-level factors.

Table 1: Classification of facilitators.

\begin{tabular}{|l|l|l|}
\hline \hline First-level facilitators & \multicolumn{1}{|c|}{ Second-level facilitators } & \multicolumn{1}{c|}{ Critical points } \\
\hline \multirow{5}{*}{ Climate } & Global irradiance & $\begin{array}{l}\text { Less than } 4,500 \mathrm{Wh} / \mathrm{m}^{2} / \mathrm{day}=0 \\
\text { More than } 5,000 \mathrm{Wh} / \mathrm{m}^{2} / \mathrm{day}=1\end{array}$ \\
\cline { 2 - 3 } Orography & Average temperature & $\begin{array}{l}\text { More than } 45^{\circ} \mathrm{C}=0 \\
\text { Less than } 15^{\circ} \mathrm{C}=1\end{array}$ \\
\hline \multirow{5}{*}{ Location } & $\begin{array}{l}\text { Less than } 3 \%=1 \\
\text { More than } 30 \%=0\end{array}$ \\
\cline { 2 - 3 } & Orientation & $\begin{array}{l}\text { Between } 337.5^{\circ} \text { and } 22.5^{\circ}=0 \\
\text { Between } 157.5^{\circ} \text { and } 202.5^{\circ}=1\end{array}$ \\
\cline { 2 - 3 } & Shade & $\begin{array}{l}\text { Shaded areas }=0 \\
\text { Illuminated areas }=1\end{array}$ \\
\hline \multirow{2}{*}{ Land use } & $\begin{array}{l}\text { Compatibility less than } 0.04=0 \\
\text { Compatibility more than } 0.25=1\end{array}$ \\
\cline { 2 - 3 } & Proximity to road access & $\begin{array}{l}\text { More than } 2,000 \mathrm{~m}=0 \\
\text { Less than } 300 \mathrm{~m}=1\end{array}$ \\
\cline { 2 - 3 } & Proximity to electricity lines & $\begin{array}{l}\text { More than } 2,000 \mathrm{~m}=0 \\
\text { Less than } 300 \mathrm{~m}=1\end{array}$ \\
\cline { 2 - 3 } & Proximity to urban areas & $\begin{array}{l}\text { More than } 5,000 \mathrm{~m}=0 \\
\text { Less than } 1,000 \mathrm{~m}=1\end{array}$ \\
\hline
\end{tabular}


And concerning restrictions, those established in the literature (e.g., Arán et al., 2008; Aydin et al., 2013) were considered, as Table 2 shows.

Table 2: Constraints.

\begin{tabular}{|l|l|}
\hline \multicolumn{1}{|c|}{ Criteria } & \multicolumn{1}{c|}{ Constraint area } \\
\hline Protected areas & The perimeter of protected areas \\
\hline Water reservoirs & The perimeter of reservoirs \\
\hline Installations & The perimeter of the installation \\
\hline Roads & Road width \\
\hline Ravines & $5 \mathrm{~m}$ from public water domain \\
\hline Isolated housing & The perimeter of the built up areas \\
\hline Population area & The perimeter of the populated area \\
\hline Main roads & $20 \mathrm{~m}$ from the centre axis \\
\hline Sea-land limits & $100 \mathrm{~m}$ inland from the shore \\
\hline Military areas & The perimeter from military area \\
\hline Slope & Areas with $>40 \%$ slope \\
\hline Minimum surface area & Plots with surface area $>0.012 \mathrm{~km}^{2}$ \\
\hline
\end{tabular}

Stage 3: Territorial resource map and territorial constrained map. The third stage consists of obtaining the territorial resource map and the territorial constrained map. In order to create the territorial resource map (TRM), the thematic layers of the factors are made in raster format, as it is adequate to represent spatial variables of continuous nature (e.g., terrain slopes, solar radiation, and temperature). As these layers have different measurement units, it is necessary to standardize them in order to carry out a joint analysis. In this case a fuzzy standardization is used (between the values 0 and 1) from a sigmoidal membership function (Eastman, 2003). To this end, it is necessary to identify the critical point of transition between 0 and 1 in each factor.

Furthermore, not all factors influence with equal weight. In order to assign this weight in a hierarchical process, deliberation starts with the so-called first-level factors. For this, a square matrix is created where the pairwise comparison of its factors can be carried out. A value is assigned to each element of the matrix which represents the relative importance of the factor in the row and column in relation to a scale from 9 (most importance) to 1/9 (least importance). The main eigenvector of the matrix, which represents the order of priority of factors, determines their weights, whereas from the maximum eigenvector, a quantitative measurement of the reliability of the assigned values (consistency ratio) is obtained. This value should be less than 0.1 (Kablan, 2004). This same process is used for the rest of the levels of factors in the hierarchy. The final weight of each factor is obtained by multiplying the weight of the factors, taking into consideration their permanency at each level of the hierarchy. Once the definite weights are calculated, the territorial resource map is achieved. Each pixel takes on a suitable value through the linear weighted summation (Voogd, 1983) of the thematic layers that represent the different factors. In this map, the most suitable areas will take on a value closer to 1 and the least suitable areas will take on values closer to 0 .

In order to obtain the territorial resource map, the first-level factors considered are climate, orography, and location. The climate factor was evaluated through two components that directly influence the performance of the photovoltaic facilities (global irradiance and average temperature). The data were obtained from the Solar Map of the Canary Islands by GRAFCAN 
(2013). Global solar irradiation determines the amount of photovoltaic energy that can be obtained depending on the solar climatic areas where the plant is placed (see Figure 4).

A photovoltaic solar power station is efficient when irradiation is higher than 4,500 $\mathrm{Wh} / \mathrm{m}^{2} /$ day and the areas with irradiation over $5,000 \mathrm{Wh} / \mathrm{m}^{2} /$ day are considered the most appropriate (e.g., Arán et al., 2008; Aydin et al., 2013). These values were taken into account to determine the cut-off points in the fuzzy standardization. Applying an increasing sigmoidal membership function between these values, we obtain the standardized irradiation thematic layer included in Figure 5.

\section{Figure 4: Spatial distribution of global irradiance (Wh/m2/day).}

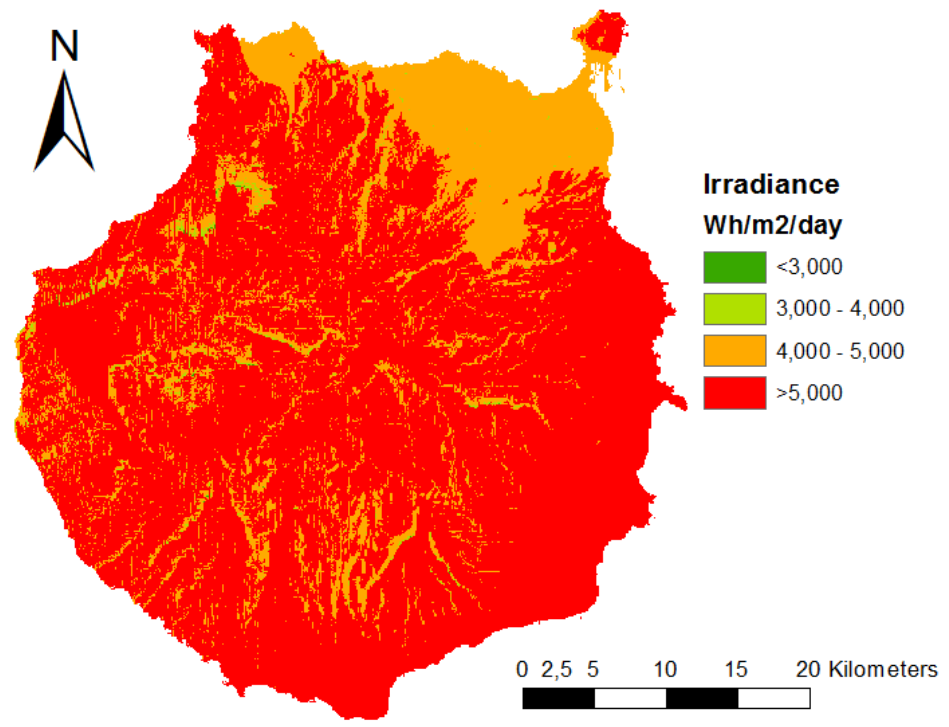

Source: Prepared from GRAFCAN data.

Figure 5: Standardized global irradiance thematic layer.

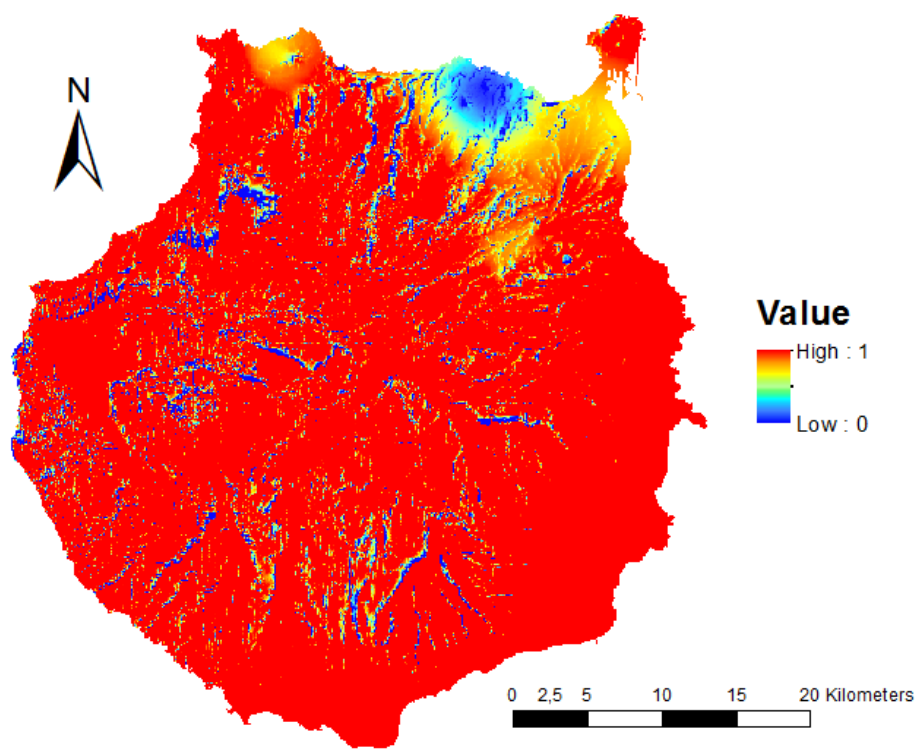

Source: Prepared from GRAFCAN data. 
As far as the climate factor refers, photovoltaic systems lose power when their temperature increases. Thus, for the same degree of solar irradiation, a photovoltaic system will produce less energy in a warmer area than in a cooler one (Chenlo \& Abella, 2006). In our research, those areas with an average temperature lower than $15^{\circ} \mathrm{C}$ will be the most appropriate and the least will be those that go over $45^{\circ} \mathrm{C}$ environmental temperature.

The evaluation of orographic factors was carried out by a digital terrain model available in the SDI of the Canary Islands done by GRAFCAN (http://tiendavirtual.grafcan.es/index.jsf). Concerning the first orographic criteria, the areas with steep slopes are not suitable locations for the construction of these facilities since the work needed to prepare them would greatly impact on the environment. This is the reason why the standard set for areas that are not appropriate are those that have more than a 30\% slope and the most appropriate ones are those that have less than a 3\% slope (e.g., Arán et al., 2008; Aydin et al., 2013). Moreover, areas orientated towards the South will have much more significant solar resources than those areas that are facing North. This circumstance indicates that the orientation of the hillsides should be another factor to consider when evaluating this territorial resource. In this case, for the standardization we have considered that the hillsides with an orientation between $157.5^{\circ}$ and $202.5^{\circ}$ will be the most suitable, and those orientated between $337.5^{\circ}$ and $22.5^{\circ}$ will not be suitable. Furthermore, photovoltaic power that reaches an area will also decrease if it is in the shade. The shade varies during the day and throughout the year, depending on the orography of the terrain and the position of the sun. This is why an azimuth and the altitude of the sun were calculated in twelve positions in relation to the latitude of the island (combining the sunrise, midday, and sunset in the four seasons of the year). With this data, a thematic layer was obtained (see Figure 6). It includes the average values of shade between 130 (value of maximum illumination) and 0 (value of complete shade). To determine the cut-off points of standardization, it was estimated that an area will be in shade when the values are less than 80 and those areas with values over 110 are the most illuminated ones.

\section{Figure 6: Shade analysis from a GIS.}

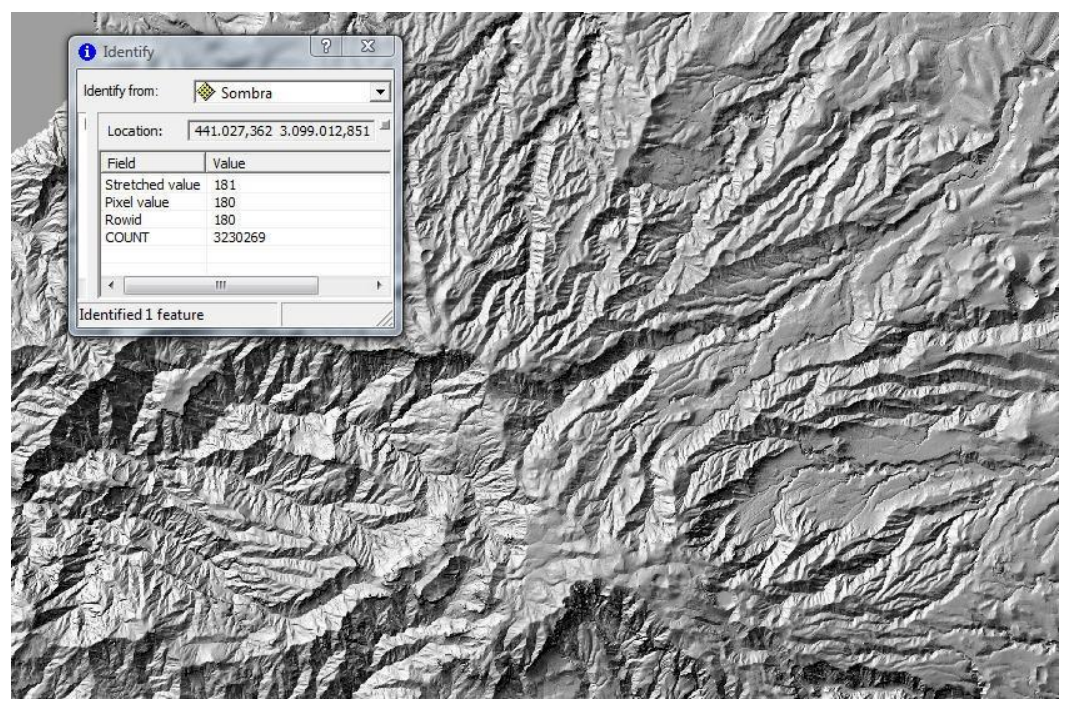

Source: Prepared from GRAFCAN data. 
For the evaluation of the four second-level factors that make up the location, the 1:5.000 land use and topography maps available in the Spatial Data Infrastructure of the Canary Islands were used (http://tiendavirtual.grafcan.es/visor.jsf?currentSeriePk=1). In relation to the land use factor, a classification through pairwise comparison was established (see Table 3 ). The thematic layer was standardized from this classification, taking into consideration that the areas with a compatibility lower than 0.04 are not suitable and the most adequate areas are those with compatibility of over 0.25 .

Table 3: Classification of land use. Consistency ratio (CR): 0.02.

\begin{tabular}{|l|c|}
\hline Location types & Compatibility \\
\hline $\begin{array}{l}\text { Urban areas, infrastructures, and industrial sites. Beaches and dunes. Pools, } \\
\text { ponds, damns, and salt lakes. Pine forest. Quarries and mines. }\end{array}$ & 0.01 \\
\hline Forests and areas with autochthonous trees. & 0.04 \\
\hline Flowers and fruit trees. Vegetable crops. & 0.06 \\
\hline Sandbars, landfills, and tips. & 0.11 \\
\hline Coastal and inland scrub. & 0.16 \\
\hline Abandoned cultivation and land with little vegetation. & 0.25 \\
\hline Deteriorated scrubland and grasslands. Land without vegetation. & 0.39 \\
\hline
\end{tabular}

We have also considered the proximity of road access to the site, as it facilitates the access for the installation and maintenance of the equipment (see Figure 7). The availability of a suitable electrical power supply is also necessary in the area, so it facilitates the connection of the photovoltaic installation to the existing network. Therefore, the road access and electrical power supply are territorial resources to be considered, as their distance or proximity from the site can increase or reduce the infrastructure costs or make its construction not feasible. To standardize those criteria, the reduced surface and the uneven orography of the island were factors taken into account. Thus the following was established: $300 \mathrm{~m}$ as optimal distance and 2,000 $\mathrm{m}$ as maximum distance to any electricity power supply and transport links.

\section{Figure 7: Road network analysis from a GIS.}

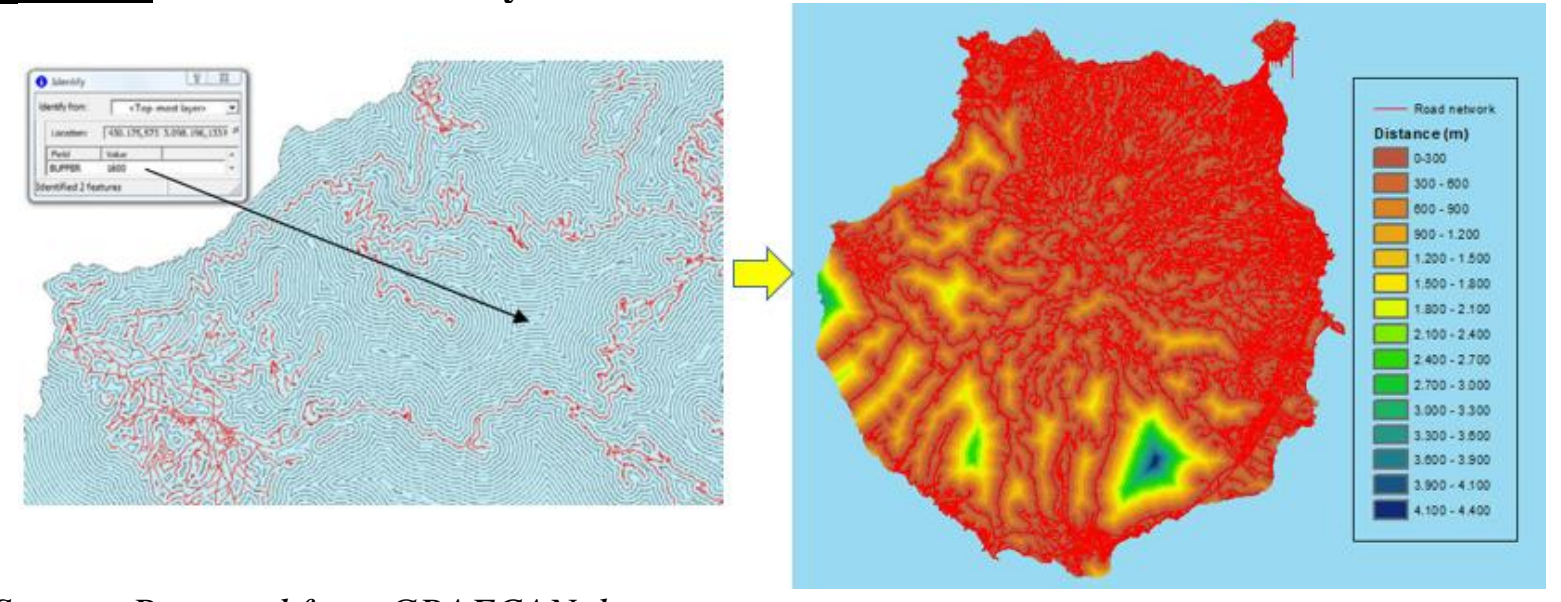

Source: Prepared from GRAFCAN data.

Finally, we have estimated that the proximity to urban areas is a second-level factor that also improves the viability of the photovoltaic plant, as it reduces transmission loss of generated 
electricity. Taking into consideration the territorial context, these stations should not be further than $5,000 \mathrm{~m}$ from urban centres and the best locations would be those below $1,000 \mathrm{~m}$.

Next, all factors were weighed through pairwise comparison (Saaty, 1977) considering the two levels. In the first level, it was established that climate factors are the most important as electricity production of the photovoltaic energy plant depends on the weather (see Table 4). The second degree of importance was given to orographic factors as the topography of the land (e.g., orientation of hillsides, slopes, shade created by the land orography) can condition the feasibility of the plant. The least relative importance was assigned to the location of this type of installation, considering the physical resources in that area.

Table 4: Pairwise comparison matrix of first-level factors and calculated weights. CR: 0.002 .

\begin{tabular}{|l|c|c|c|l|}
\hline & Climate & Orography & Location & Weights \\
\hline Climate & 1 & 2 & 7 & 0.6025 \\
\hline Orography & $1 / 2$ & 1 & 4 & 0.3151 \\
\hline Location & $1 / 7$ & $1 / 4$ & 1 & 0.0824 \\
\hline
\end{tabular}

Of the nine second-level factors, the four most critical in capturing photovoltaic energy were given the highest weights (see Table 5): solar irradiation (47.8\%), shaded areas in the territory $(17.9 \%)$, temperature $(12.5 \%)$, and hillside orientation (10.5\%). Next ranked are: land use (3.9\%), slope (3.1\%), electricity supply (2.2\%), transport network (1.5\%), and distance to urban areas $(0.6 \%)$.

Table 5: Final weight of criteria.

\begin{tabular}{|l|l|c|}
\hline First-level factors & \multicolumn{1}{|c|}{ Second-level factors } & Final weight \\
\hline \multirow{2}{*}{$\begin{array}{l}\text { Climate } \\
\mathrm{w}=0.603\end{array}$} & Global irradiance $\mathrm{w}=0.793$ & 0.478 \\
\cline { 2 - 3 } $\begin{array}{l}\text { Orography } \\
\mathrm{w}=0.315\end{array}$ & Average temperature $\mathrm{w}=0.207$ & 0.125 \\
\hline \multirow{4}{*}{$\begin{array}{l}\text { Location } \\
\mathrm{w}=0.082\end{array}$} & Slopes $\mathrm{w}=0.098$ & 0.031 \\
\cline { 2 - 3 } & Orientation $\mathrm{w}=0.334$ & 0.105 \\
\cline { 2 - 3 } & Shade $\mathrm{w}=0.568$ & 0.179 \\
\cline { 2 - 3 } & $\begin{array}{l}\text { Land use } \mathrm{w}=0.471 \\
\text { Proximity to road access } \\
\mathrm{w}=0.188\end{array}$ & 0.039 \\
\cline { 2 - 3 } & $\begin{array}{l}\text { Proximity to electricity lines } \\
\mathrm{w}=0.267\end{array}$ & 0.015 \\
\cline { 2 - 3 } & $\begin{array}{l}\text { Proximity to urban areas } \\
\mathrm{w}=0.074\end{array}$ & 0.022 \\
\hline
\end{tabular}

Taking this weighing into account, the territorial resource map was obtained through the linear weighted combination of the factor layers (see Figure 8). 
Figure 8: Territorial resource map.

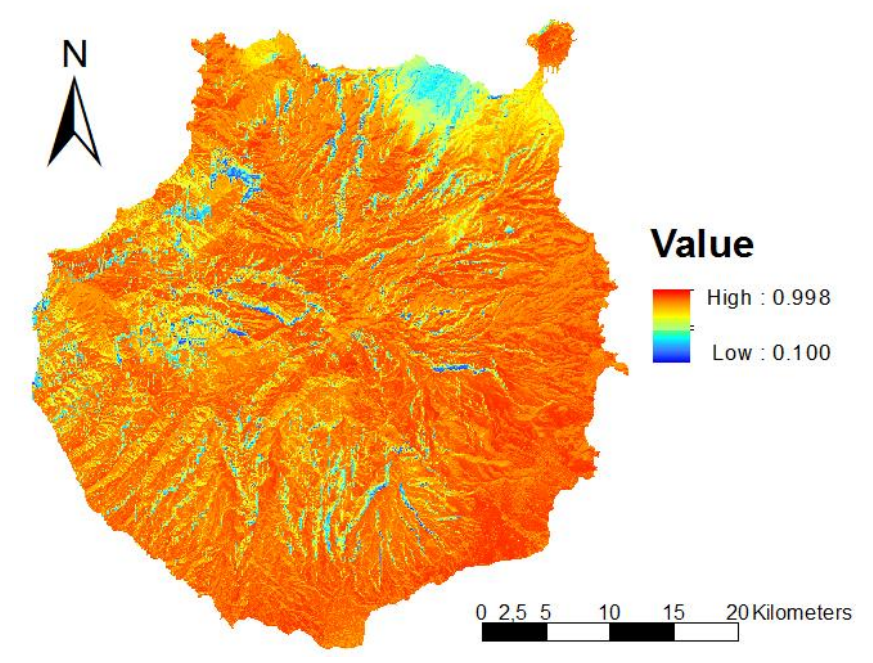

Source: Prepared from GRAFCAN data.

The next step in the process is the elaboration of the map of territorial constraints (MTC). The thematic layers that make up this map (such as legislation, environmental aspects, and topography) are compiled in vector format. This format, in contrast to the raster one, defines and measures accurately the surface of the areas which are suitable for the activity researched. Due to its dichotomous nature, its standardization is carried out through a Boolean method (appropriate, excluded).

The map of territorial restrictions identifies the area of the territory that can effectively be used for the development of photovoltaic energy, considering the restrictions established in the literature (e.g., Arán et al., 2008; Aydin et al., 2013) and already included in Table 2. In relation to the protected areas, the positioning of the photovoltaic energy plants should take into account the biodiversity conservation policies in the territory. To carry out this study, the protected areas that have been established as sensitive areas by the Canarian Network of Natural Spaces and the Natura 2000 network were included. Both networks were considered because, even though in general terms the territorial delimitations are quite concurrent, there are some areas that are not common. Restrictions related to the water reservoirs are due to the difficulty involved in constructing the photovoltaic plants over surface areas covered by water. Therefore, this restriction was limited to the perimeter of lakes, ponds, swamp areas, reservoirs, and pools, as well as the perimeter of installations such as industrial buildings, shelters, and bridges. The existing road width in the territory was also excluded.

With respect to the watercourse of the ravine, in Decree 86/2002, which regulates public water domain, Article 12 states that the watercourses of the ravines are subject to, as a general rule and through its whole longitude dimension, an easement for public use of $5 \mathrm{~m}$ width. In turn, the restriction that makes reference to the distance to populated areas and isolated housing will affect the perimeter of the urban areas (dense and sparse), and also the isolated built-up areas. The Canarian Road Regulations (Decree 131/1995) were considered in terms of road access, so the safety distance of $20 \mathrm{~m}$ from the axis was established. 
Santana Sarmiento, Álamo Vera, \& De Saá Pérez

Figure 9: Map of Territorial Constraints (MTC).

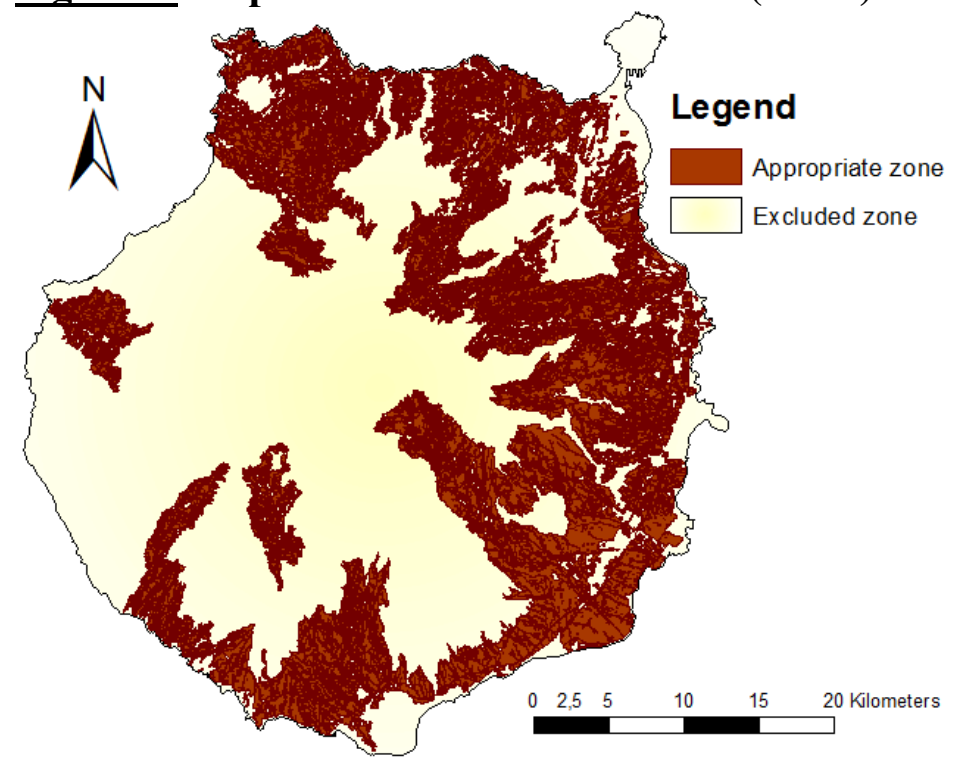

Source: Prepared from GRAFCAN data.

Article 43 of Royal Decree 1471/1989, which establishes coastal law, states that the easement of the sea-land protection will extend to 100 meters, measured from inland to the inside limit of the sea shore. Moreover, Article 30 of Constitutional Law 5/2005 states that "in the areas of national territory considered of interest to defence [...] may be limited the property rights of goods located in them, owned by domestic and foreign people, according to what is determined by law." Those areas with more than a $40 \%$ slope were also rejected as suitable surface areas for the setting of photovoltaic plants. Finally, so as not to scatter the number of photovoltaic plants and to avoid an excessive visual impact, the only land plots that were taken into account are those that can hold installations which are able to offer over $1 \mathrm{MWp}$ (Megawatt peak) of electricity, as the average surface area needed to install $1 \mathrm{kWp}$ is $12 \mathrm{~m}^{2}$. Figure 9 shows the result obtained from the map of territorial constraints.

As we are dealing with a vector map, it delimits with precision the areas where it is possible to place the photovoltaic plants.

Stage 4: Available territorial resource map. The objective of the fourth stage is to obtain the available territorial resource map (ATRM), which will illustrate the territorial resource that can actually be used considering the restrictions. To do this, unsuitable areas are excluded from the map. This is an essential document for the evaluation of available resources in the territory. In this document, the influence of all the factors with respect to their assigned relative weight is synthesized. Thus, the areas that obtain a value 0 in some factors are not totally excluded if they have a highly relative weight in others. The application of restrictions accurately delimits the territorial area susceptible to use. Moreover, the system permits the information to be updated without the need to repeat the whole process each time.

The ATRM is then obtained by adding the restrictions to the territorial resource map (see Figure 10). To facilitate visualization, four suitability levels were used: poor (0-0.25), moderate (0.25-0.50), suitable (0.50-0.75), and highly suitable (0.75-1). 
Figure 10: Available territorial resource map and municipalities of Gran Canaria.

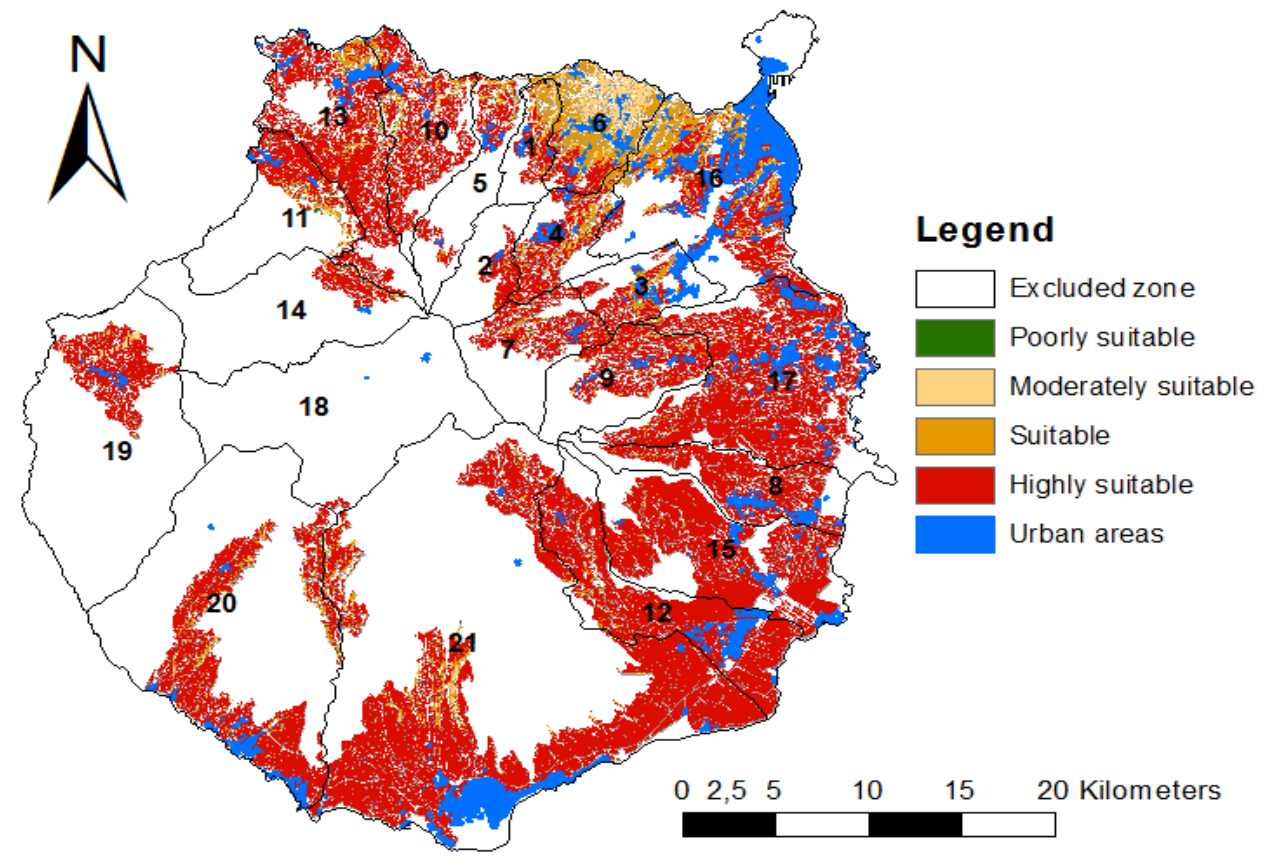

Source: Prepared from GRAFCAN data.

$\begin{array}{llllll}1 & \text { Firgas } & 8 & \text { Ingenio } & 15 & \text { Agüimes } \\ 2 & \text { Valleseco } & 9 & \text { Valsequillo de G.C. } & 16 & \text { Las Palmas de Gran Canaria } \\ 3 & \text { Santa Brígida } & 10 & \text { Santa María de Guía de G.C. } & 17 & \text { Telde } \\ 4 & \text { Teror } & 11 & \text { Agaete } & 18 & \text { Tejeda } \\ 5 & \text { Moya } & 12 & \text { Santa Lucía } & 19 & \text { San Nicolás de Tolentino } \\ 6 & \text { Arucas } & 13 & \text { Gáldar } & 20 & \text { Mogán } \\ 7 & \text { Vega de San Mateo } & 14 & \text { Artenara } & 21 & \text { San Bartolomé de Tirajana }\end{array}$

This map delimits the areas where it is possible to place the photovoltaic plants and evaluates them according to the suitability of their location. Table 6 shows the available surface area in accordance to suitability level.

Table 6: Area suitability for photovoltaic plant placement.

\begin{tabular}{|l|c|r|}
\hline \hline Suitability & Pixel value & Area $\left.\mathbf{( k m}^{2}\right)$ \\
\hline Poorly suitable & $0.00-0.25$ & 0.81 \\
\hline Moderately suitable & $0.25-0.50$ & 17.71 \\
\hline Suitable & $0.50-0.75$ & 41.83 \\
\hline Highly suitable & $0.75-1.00$ & 433.10 \\
\hline Total & & $\mathbf{4 9 3 . 4 5}$ \\
\hline
\end{tabular}

Stage 5: Available territorial resource index. The process culminates with the calculation of a numerical value: the available territorial resource index (ATRI). This index enables to carry out a comparative evaluation among territories. This index was obtained as a result of multiplying the arithmetic mean of the value that the ATRM pixels take on by the available areas obtained from the MTC, according to the following equation: 


$$
A T R I=\frac{\sum_{i=1}^{n} C R T_{i}}{n} * S=C R T * S
$$

where $C R T i$ is the value that represents the quality of the territorial resource of each pixel that the GIS calculates for each municipality and the whole island, $n$ is the number of pixels of the available area, and $S$ is the available surface area.

Table 7 shows the value of the CRT, that is, the average suitability of the pixels for Gran Canaria and each of its 21 municipalities; the available surface area (S), the ATRI and, in the fourth column, its relative value for each municipality compared to the whole island.

\begin{tabular}{|c|c|c|c|c|}
\hline $\begin{array}{l}\text { Table 7: Available territorial } \\
\text { resource indicator per } \\
\text { municipalities in Gran }\end{array}$ & $\begin{array}{c}\text { Average } \\
\text { Suitability }(C R T)\end{array}$ & $\begin{array}{l}\operatorname{urface}_{\mathbf{k} \mathbf{k}^{2}} \\
(S)\end{array}$ & $\begin{array}{c}\text { ATRI } \\
(C R T * S)\end{array}$ & $\frac{\text { ATRI }_{\mathbf{i}}}{\text { ATRI }_{\text {G.C. }}}$ \\
\hline Gran Canaria (whole island) & 0.853 & 493.45 & 420.912 & 1.000 \\
\hline Agaete & 0.799 & 10.73 & 8.575 & 0.020 \\
\hline Agüimes & 0.918 & 43.84 & 40.241 & 0.096 \\
\hline Artenara & 0.853 & 4.46 & 3.806 & 0.009 \\
\hline Arucas & 0.581 & 19.40 & 11.273 & 0.027 \\
\hline Firgas & 0.732 & 5.81 & 4.255 & 0.010 \\
\hline Gáldar & 0.850 & 32.09 & 27.276 & 0.065 \\
\hline Ingenio & 0.905 & 18.95 & 17.147 & 0.041 \\
\hline Las Palmas de G. C. & 0.769 & 27.84 & 21.406 & 0.051 \\
\hline Mogán & 0.853 & 37.82 & 32.256 & 0.077 \\
\hline Moya & 0.794 & 5.96 & 4.732 & 0.011 \\
\hline San Bartolomé de Tirajana & 0.888 & 106.09 & 94.209 & 0.224 \\
\hline San Nicolás de Tolentino & 0.846 & 14.51 & 12.276 & 0.029 \\
\hline Santa Brígida & 0.809 & 7.12 & 5.762 & 0.014 \\
\hline Santa Lucía de Tirajana & 0.900 & 39.81 & 35.829 & 0.085 \\
\hline Santa María de Guía de G. C. & 0.819 & 20.98 & 17.185 & 0.041 \\
\hline Tejeda & 0.898 & 0.38 & 0.345 & 0.001 \\
\hline Telde & 0.885 & 55.84 & 49.418 & 0.117 \\
\hline Teror & 0.788 & 12.26 & 9.663 & 0.023 \\
\hline Valleseco & 0.853 & 3.38 & 2.879 & 0.007 \\
\hline Valsequillo de G. C. & 0.862 & 14.82 & 12.771 & 0.030 \\
\hline Vega de San Mateo & 0.854 & 11.36 & 9.703 & 0.023 \\
\hline
\end{tabular}

\section{Results}

From the results shown in Table 6, it can be seen that the available surface area is $493.45 \mathrm{~km}^{2}$, which implies that $31.6 \%$ of land is suitable for the placement of photovoltaic power plants. It should be highlighted that out of this available surface area only $3.8 \%$ is poorly or moderately suitable and $87.8 \%$ is highly suitable. Table 7 shows that only Firgas (0.732) and Arucas (0.581) are least suitable 
for the localization of photovoltaic power plants, and the remaining 19 municipalities of the island of Gran Canaria are highly suitable for these facilities, according to the methodology deployed.

After evaluating the different municipalities through the relative ATRI (Table 7), it can be observed that the most suitable areas are located in the South and South-East of the island: San Bartolomé de Tirajana (22.4\% of the whole island), Telde (11.7\%), Agüimes (9.6\%), Santa Lucía de Tirajana (8.5\%), and Mogán (7.7\%). These results align with the fact that some of these municipalities are home to the main renewable energy plants in the island. Moreover, in the North of Gran Canaria there are also some municipalities with a high ATRI: Gáldar (6.5\%), Las Palmas de Gran Canaria (5.1\%), and Santa María de Guía de G.C. (4.1\%), which could be good locations for the development of this type of energy. However, some municipalities, such as Artenara $(0.9 \%)$, Valleseco $(0.7 \%)$, and Tejeda $(0.1 \%)$, located at the centre of the island, with medium to high suitability index (CRT) have a low indicator due to the fact that available surface area is a condition to the value of the ATRI. For example, Tejeda, with a 0.898 CRT, has only $0.38 \mathrm{~km}^{2}$ of available surface area, mainly due to the fact that it is a natural protected area.

\section{Conclusion}

This study proposes a new methodology to identify the best localization of photovoltaic power plants on the island of Gran Canaria, by assessing those physical territorial resources involved in the development of that type of renewable energy through two instruments: the available territorial resource map (ATRM) and the available territorial resource index (ATRI). In order to achieve this objective, we have used multi-criteria analysis through an analytical hierarchy process with geographical information systems. The empirical analysis concluded that there is a large percentage of land that shows a highly suitable qualification, which indicates the existence of an excellent territorial potential in the municipalities of Gran Canaria for the settingup of photovoltaic plants. According to the results, 31.6\% of land in Gran Canaria can be used for the placement of photovoltaic power plants. Out of this available surface area, $87.8 \%$ is highly suitable. Considering that only $3.4 \%$ of the energy currently consumed in Gran Canaria stems from photovoltaic energy, our findings indicate the existence of a very significant potential for the development of this renewable energy. Finally, the calculation of the ATRI in the different municipalities of the island enables the identification and ranking of those most suitable for investment in this activity. These are those located in the South and South-East of the island (San Bartolomé de Tirajana, Telde, Agüimes, Santa Lucía de Tirajana, and Mogán), and three municipalities in the North (Gáldar, Las Palmas de Gran Canaria, and Santa María de Guía de G.C.). Therefore, these municipalities have the best natural conditions related to the factors considered in our study - climate, orography, and location of physical resources - for the setting-up of photovoltaic power plants.

Renewable energy, and specifically solar photovoltaic energy, was the industry selected for the empirical study. The reasons for this decision are three-fold: (a) this sector is likely to offer interesting business opportunities; (b) it is a strategic sector for the economic growth in Spain, as well as in the Canary Islands; and (c) it is an economic activity where location is a key success factor, as firms usually intend to optimize natural resources. The study was carried out on the island of Gran Canaria (Spain) and its municipalities, with a relevant potential use for both public authorities and private investors.

This work shows that the integration of multi-criteria analysis with geographic information systems is an effective tool to assess the available territorial resource for the development of a 
particular economic activity such as the installation of photovoltaic power plants. This evaluation was carried out on the basis of an analytical hierarchy process structured in five stages. To do this, nine facilitators were defined and classified into three groups (climate, orography, and location) as well as twelve restrictions. The result was the available territorial resource map (ATRM) which has a double objective: (a) it accurately marks the territorial area susceptible to use as a territorial resource by obtaining the restrictions in vector format and (b) it quantifies the influence of the available resources according to the relative weight that was assigned to each of them. Taking the ATRM as a reference, the available territorial resource index (ATRI) was obtained. This index synthesizes the information of the map through a numerical value which allows territorial comparison. A sigmoidal distribution for the evaluation criteria measurements was chosen, which represents a methodological contribution to the existing literature as no precedents have been found in this respect.

This research has important practical implications for policymakers. On the basis of the scientific information that the ATRM and ATRI offer, a land use policy that strengthens those areas with better conditions for the development of a particular economic activity can be formulated. In this vein, the assessment of all the available resources is particularly important in insular territories where the need to assign the best use to the existing limited land is critical. Therefore, the ATRM and the ATRI favour the strategic decision-making aimed at: (a) environmental preservation, delimiting perfectly the areas where it is viable to place a particular activity; (b) economic viability, classifying the territory according to its suitability for the economic development; and (c) social equity, making it possible to plan between needs and available resources throughout the territory. Furthermore, the system allows the updating of information independently. This facilitates the tracking of resources over time, without the need to repeat the whole process each time.

Moreover, this methodology can be applied to the study of synergies between different and potentially complementary sectors. For instance, the synergies that might exist between agriculture and livestock activities as well as the sub-sectors of renewable energy such as biomass, bio-fuel, and bio-gas. Taking advantage of the possibilities resulting from the integration of multi-criteria analysis with geographic information systems, resulting applications can enable the classification and evaluation of the territory, indicating which areas would be suitable for the development of one or more activities and which ones will be more appropriate to make the most of the synergies between different activities.

\section{Acknowledgements}

We thank several anonymous referees for additional helpful comments and suggestions. GRAFCAN is also gratefully acknowledged for contributing key data to this research.

\section{References}

Arán, J., Espín, A., Aznar, F., Zamorano, M., Rodríguez, M., \& Ramos, A. (2008). Environmental decision-support systems for evaluating the carrying capacity of land areas: optimal site selection for grid-connected photovoltaic power plants. Renewable and Sustainable Energy Reviews, 12(9), 2358-2380. https://doi.org/10.1016/j.rser.2007.06.011

Armstrong, H.W, Giordano, B., Kizos, T., Macleod, C., Olsen, L.S., \& Spilanis, I. (2012). The European Regional Development Fund and island regions: an evaluation of the 2000-06 and 2007-13 programs. Island Studies Journal, 7(2), 177-198. 
Aydin, N.Y., Kentel, E., \& Duzgun, S. (2013). GIS-based site selection methodology for hybrid renewable energy systems: a case study from western Turkey. Energy Conversion and Management, 70(June), 90-106. https://doi.org/10.1016/j.enconman.2013.02.004

Baldacchino, G. (2004). The coming age of island studies. Tijdschrift voor Economische en Sociale Geografie, 95(3), 272-283. https://doi.org/10.1111/j.1467-9663.2004.00307.x

Balkytè, A., \& Peleckis, K. (2010). Mapping the future sustainable competitiveness resources: aspects of forests ownership. Journal of Business Economics and Management, 11(4), 630-651. https://doi.org/10.3846/jbem.2010.31

Bueno, C., \& Carta, J.A. (2006). Wind powered pumped hydro storage systems, a means of increasing the penetration of renewable energy in the Canary Islands. Renewable and Sustainable Energy Reviews, 10(4), 312-340. https://doi.org/10.1016/j.rser.2004.09.005

Calero, R., \& Carta, J.A. (2004). Action plan for wind energy development in the Canary Islands. Energy Policy, 32, 1185-1197. https://doi.org/10.1016/S0301-4215(03)00082-X

Calero. R. (2011). Los cimientos de un mundo sostenible. CCPC, Santa Cruz de Tenerife.

Canarian Statistics Institute (2016). Series anuales. Municipios. 2000-2015. Retrieved from http://www.gobiernodecanarias.org/istac/temas_estadisticos/demografia/poblacion/cifr aspadronales/E30245A.html

Canary Islands Government (2016). Anuario energético de Canarias 2014. Consejería de Economía, Industria, Comercio y Conocimiento. Gobierno de Canarias. Canarias, España.

Retrieved from http://www.gobiernodecanarias.org/ceic/energia/temas/hidrocarburos/

Chenlo, F., \& Abella, M.A. (2006). Sistemas fotovoltaicos conectados a red: estimación de la energía generada. Era Solar: Energías Renovables, 131(1), 36-47.

Chhetri, P., \& Arrowsmith, C. (2008). GIS-based modelling of recreational potential of naturebased tourist destinations. Tourism Geographies, 10(2), 233-257. https://doi.org/10.1080/14616680802000089

Colletis-Wahl, K., \& Pecqueur, B. (2001). Territories, development and specific resources: what analytical framework? Regional Studies, 35(5), 449-459. https://doi.org/10.1080/713693825

Deas, I., \& Giordano, B. (2001). Conceptualising and measuring urban competitiveness in major English cities: an exploratory approach. Environment and Planning, 33, 1411-1429. https://doi.org/10.1068/a33142

Del Río, P., \& Burguillo, M. (2009). An empirical analysis of the impact of renewable energy deployment on local sustainability. Renewable and Sustainable Energy Reviews, 13(67), 1314-1325. https://doi.org/10.1016/j.rser.2008.08.001

Dey, P.K., \& Ramcharan, E.K. (2008). Analytic hierarchy process helps select site for limestone quarry expansion in Barbados. Journal of Environmental Management, 88(4), 13841395. https://doi.org/10.1016/j.jenvman.2007.07.011

Dögl, C., \& Holtbrügge, D. (2010). Competitive advantage of German renewable energy firms in Russia: an empirical study based on Porter's diamond. Journal for East European Management Studies, 15(1), 34-58.

Eastman, J.R. (2003). Idrisi Kilimanjaro: Tutorial. Worcester MA: Clark University.

Eslami, A., \& Roshani, M. (2009). The selection of suitable sites for tourist settlement by GIS with emphasis ecotourism in Southern part of Caspian Sea. Journal of Applied Sciences, 9(21), 3894-3899. https://doi.org/10.3923/jas.2009.3894.3899

Europe 2020 (2010). A European strategy for smart, sustainable and inclusive growth. Communication from the Commission. Brussels, European Commission. Retrieved from 
http://ec.europa.eu/eu2020/pdf/COMPLET\%20EN\%20BARROSO\%20\%20\%20007\% 20-\%20Europe\%202020\%20-\%20EN\%20version.pdf

Gallardo-Cobos, R., Garrido-García, D., Haro-Giménez, T., Pedraza-Jiménez, V., Ramos-Real, E., Ramos-Real, F., \& Sánchez-Zamora, P. (2011). Desarrollo rural territorial. Metodología y aplicación para el estudio de casos. Ra-Ma: Ministerio de Medio Ambiente y Medio Rural y Marino.

Gómez, M., \& Barredo, J. (2005). Sistemas de información geográfica y evaluación multicriterio en la ordenación del territorio. Madrid: Ra-Ma.

GRAFCAN, Cartográfica de Canarias S.A. (2013). Retrieved from http://visor.grafcan.es/visorweb/

Hajehforooshnia, S., Soffianian, A., Mahiny, S., \& Fakheran, S. (2011). Multi-objective land allocation (MOLA) for zoning Ghamishloo Wildlife Sanctuary in Iran. Journal for Nature Conservation, 19(4), 254-262. https://doi.org/10.1016/j.jnc.2011.03.001

Hossain, M.S., Chowdhury, R., Das, N.G., \& Rahaman, M.M. (2007). Multi-criteria evaluation approach to GIS-based land-suitability classification for tilapia farming in Bangladesh. Aquaculture International, 15(6), 425-443. https://doi.org/10.1007/s10499-007-9109-y

Huggins, R. (2003). Creating a U.K. competitiveness index: regional and local benchmarking. Regional Studies, 37(1), 89-96. https://doi.org/10.1080/0034340022000033420

Izquierdo, S., Rodrigues, M., \& Fueyo, N. (2008). A method for estimating the geographical distribution of the available roof surface area for large-scale photovoltaic energy-potential evaluations. Solar Energy, 82(10), 929-939. https://doi.org/10.1016/j.solener.2008.03.007

Kablan, M.M. (2004). Decision support for energy conservation promotion: an analytic hierarchy process approach. Energy Policy, 32(10), 1151-1158. https://doi.org/10.1016/S0301-4215(03)00078-8

Kontos, T., Komilis, D., \& Halvadakis, K. (2005). Siting MSW landfills with a spatial multiple criteria analysis methodology. Waste Management, 25(8), 818-832. https://doi.org/10.1016/j.wasman.2005.04.002

Malczewski J. (1999). GIS and multicriteria decision analysis. New York: John Wiley \& Sons.

Malczewski, J. (2006). GIS-based multicriteria decision analysis: a survey of the literature. International Journal of Geographical Information Science, 20(7), 703-726. https://doi.org/10.1080/13658810600661508

Marinoni, O. (2004). Implementation of the analytical hierarchy process with VBA in ArcGIS. Computer \& Geosciences, 30(6), 637-646. https://doi.org/10.1016/j.cageo.2004.03.010

Monedero, J., García, J., Dobon, F., Yanes M.A., \& Hernández, F. Calculation of PV Potential Maps in the Canary Islands. Retrieved from http://www.idecan.grafcan.es/resources/MapaSolar.pdf

Moon, H.C., Rugman, A.M., \& Verbeke, A. (1998). A generalized double diamond approach to the global competitiveness of Korea and Singapore. International Business Review, 7(2), 135-150. https://doi.org/10.1016/S0969-5931(98)00002-X

Omitaomu, O., Blevins, B., Jochem, W., Mays, G., Belles, R., Hadley, S., Harrison, T., Bhaduri, B., Neish, B., \& Rose, A. (2012). Adapting a GIS-based multicriteria decision analysis approach for evaluating new power generating sites. Applied Energy, 96(August), 292301. https://doi.org/10.1016/j.apenergy.2011.11.087

Pasqualini, V., Oberti, P., Vigetta, S., Riffard, O., Panaïotis, C., Cannac, M., \& Ferrat, L. (2011). A GIS-based multicriteria evaluation for aiding risk management Pinus pinaster Ait. Forests: a case study in Corsican Island, Western Mediterranean Region. Environmental Management, 48(1), 38-56. https://doi.org/10.1007/s00267-011-9674-8 
Perpiña, C., Martínez-Llario, J.C., \& Pérez-Navarro, A. (2013). Multicriteria assessment in GIS environments for siting biomass plants. Land Use Policy, 31(March), 326-335. https://doi.org/10.1016/j.landusepol.2012.07.014

Perez, Y., \& Ramos Real, F.J. (2008). How to make a European integrated market in small and isolated electricity systems? The case of the Canary Islands. Energy Policy, 36(11), 4159-4167. https://doi.org/10.1016/j.enpol.2008.05.019

Rutkauskas, A.V. (2008). On the sustainability of regional competitiveness development considering risk. Technological and Economic Development of Economy, 14(1), 89-99. https://doi.org/10.3846/2029-0187.2008.14.89-99

Saaty, T.L. (1977). A scaling method for priorities in hierarchical structures. Journal of Mathematical Psychology, 15(3), 234-281. https://doi.org/10.1016/0022-2496(77)90033-5

Schallenberg-Rodríguez, J. (2013). Photovoltaic techno-economical potential on roofs in regions and islands: the case of the Canary Islands. Methodological review and methodology proposal. Renewable and Sustainable Energy Reviews, 20(April), 219-239. https://doi.org/10.1016/j.rser.2012.11.078

Suárez-Vega, R., Santos-Peñate, D., Dorta-González, P., \& Rodríguez-Díaz, M. (2011). A multi-criteria GIS based procedure to solve a network competitive location problem. Applied Geography, 31(1), 282-291. https://doi.org/10.1016/j.apgeog.2010.06.002

Tegou, L., Polatidis, H., \& Haralambopoulos, D. (2010). Environmental management framework for wind farm siting: methodology and case study. Journal of Environmental Management, 91(11), 2134-2147. https://doi.org/10.1016/j.jenvman.2010.05.010

Tiba, C., Candeias, A.L.B., Fraidenraich, N., De S Barbosa, E.M., De Carvalho Neto, P.B., \& De Melo Filho, J.B. (2010). A GIS-based decision support tool for renewable energy management and planning in semi-arid rural environments of northeast of Brazil. Renewable Energy, 35(12), 2921-2932. https://doi.org/10.1016/j.renene.2010.05.009

Tuzkaya, G., Onut, S., Tuzkaya, U.R., \& Gulsun, B. (2008). An analytic process approach for locating undesirable facilities: an example from Istanbul, Turkey. Journal of Environmental Management, 88(4), 970-983. https://doi.org/10.1016/j.jenvman.2007.05.004

Vizzari, M. (2011). Spatial modelling of potential landscape quality. Applied Geography, 31(1), 108-118. https://doi.org/10.1016/j.apgeog.2010.03.001

Voogd, H. (1983). Multicriteria evaluation for urban and regional planning. London: Pion.

Wang, G., Qin, L., Li, G., \& Chen, L. (2009). Landfill site selection using spatial information technologies and AHP: a case study in Beijing, China. Journal of Environmental Management, 90(8), 2414-2421. https://doi.org/10.1016/j.jenvman.2008.12.008

Wiginton, L.K., Nguyen, H.T., \& Pearce, J.M. (2010). Quantifying rooftop solar photovoltaic potential for regional renewable energy policy. Computers, Environment and Urban Systems, 34(4), 345-357. https://doi.org/10.1016/j.compenvurbsys.2010.01.001

Yang, F., Zeng, G., Du, C., Tang, L., Zhou, J., \& Li, Z. (2008). Spatial analyzing system for urban land-use management based on GIS and multi-criteria assessment modeling. $\begin{array}{llll}\text { Progress in Natural } \quad \text { Science, } & 18(10), & 1279-1284 .\end{array}$ https://doi.org/10.1016/j.pnsc.2008.05.007 